\title{
Awareness of working women regarding To osteoporosis
}

\author{
Asmaa A. Sayed, Hanna A. Abd EL-Meged, Amina A. Mahmoud
}

\begin{abstract}
Osteoporosis is a progressive skeletal disease that affects hundreds of millions of people worldwide, predominantly postmenopausal women. The aim of this study: was to assess the awareness of working women toward osteoporosis. Research design: A descriptive research design was utilized in this study. Setting: This study was conducted in Benha University Administration. The sample: A simple random sample was used to choose 200 women. Two instruments were used. Instrument one: Social characteristics of the sample structured interview questionnaire, medical history, knowledge and practices of the studied sample. Instrument two: Osteoporosis risk factors checklist. Results: ages of $37 \%$ of the studied women from 30-40 years old, women who had no knowledge about osteoporosis were $41 \%$, women who had satisfactory practices were $69.5 \%$. Conclusion: many women had poor total knowledge about osteoporosis and poo total practice. Recommendations: Health educational program should be developed and implemented for all women to increase their awareness regarding prevention of osteoporosis.
\end{abstract}

Key words: Osteoporosis, Risk factors and Working women.

\section{INTRODUCTION}

Awareness is defined as the ability to directly know, perceive and to feel by having or showing realization, perception or knowledge. Aware implies knowledge gained through one's own perceptions or by means of outside information to formulate a state of elementary or undifferentiated consciousness that puts individual in alert cognitive state to be aware of the situation (Henriques, 2014).

Osteoporosis is a disease in which the density and quality of bone are reduced, leading to weakness of the skeleton and increased risk of fracture, particularly of the spine, wrist, hip, pelvis and upper arm. Osteoporosis and associated fractures are an important cause of mortality and morbidity (Hannon \& Murphy, 2017).

Osteoporosis is one of the diseases which affect an important sector of the population and therefore have serious impact on the community; it is a significant global public health issue, which affects 200 million women around the world and its frequency increase by age. It is expected to affect more people worldwide than ever by 2050. It is no longer confined to the growing older population but has 
implications for all age groups (ELTawab et al., 2015).

Osteoporosis is most common in postmenopausal women due to loss of sex hormones. In many affected people, bone loss is gradual and occurs without symptoms or warning signs until the disease is advanced So, osteoporosis is referred to as the "silent epidemic" (Hackley \& Kriebs, 2016).

Women are at higher risk of getting osteoporosis due to attainment of lower peak bone mass early in life and hormonal changes that occur at the menopause .Working women are more likely to have osteoporosis because they stay along time at working place, lack of exposure to sunlight and unhealthy food intake integrated disease (Anbarasi et al., 2015).

The occupational health nurse activities in primary, secondary and tertiary prevention stratiges are expected to assume an even more important role in the prevention and treatment of illness, injury and chronic in the future. The occupational health nurse play an important role regarding decrease the risk of osteoporosis among working women through educating them about warning signs of osteoporosis, healthy life style, following good nutrition, doing exercise and preventing falls during the work (Stanhope \&Lancaster, 2018).

\section{Significance of the study:}

Osteoporosis has become one of the most prevalent and costly health problems; it affects more than 75 million people worldwide. Its prevalence among Egyptian population is $10 \%$ (Fahim et al., 2015). In Egypt as $6.5 \%$ of females aged 20 years and above suffer from osteopenia and $12.6 \%$ of women in the same age group suffer from osteoporosis. Egyptian women have generally lower bone mineral density compared to women in western countries based on different studies, it has been calculated that $53.9 \%$ of postmenopausal women have osteopenia and $28.4 \%$ have osteoporosis (Mohamed \& Tayel, 2012).

\section{Purpose of the study}

The purpose of the study was to assess awareness of working women regarding osteoporosis through:-

\section{Research questions}

1) Are the working women have knowledge and practices enough regarding osteoporosis?

2) Is there a relation between socio demographic charact-eristics of working women and their knowledge and practice regarding osteoporosis? 
3) What are the most prevalent osteoporosis risk factors among working women?

4) 4-Is there a relation between working women's knowledge and their practices regarding osteoporosis?

\section{Methods}

\section{Research design:}

A descriptive research design was utilized to conduct this study.

\section{Setting:-}

This study was conducted at Benha University Administration.

\section{Sampling}

A simple random sample was used to choose $10 \%$ of women who work in Benha University Administration. The total number of study sample was 200 women out of (2000).

\section{Instruments}

Two instruments were used to collect the data:

\section{Instrument one: A struct-ured} interview questionnaire: It was developed by the investigator and supervisors; staff based on reviewing related literatures, and it was written in simple clear Arabic language. It comprised of four parts:

- Part one: It was concerned with social characteristics of studied sample. It included 7 items about: Age, place of residence, level of education marital status, monthly income, nature of work and daily working hours.

- Part two: It was concerned with the medical history of the studied sample it included 2 questions about; health problems and drugs taken related for osteoporosis, it was divided into 16 items.

- Part three: It was concerned with the knowledge of the studied sample about osteoporosis which included 40 items; 5 about meaning, 4about symptoms, 8 about causes, 4 about high risk , 4 about the risk , 9 about preventive methods and 6 about source of information.

\section{Scoring system:}

\begin{tabular}{|l|l|}
\hline Good & $>26(65 \%)$ \\
\hline Average & $20-26(50-<65 \%)$ \\
\hline Poor & $<20(<65 \%)$ \\
\hline
\end{tabular}

Instrument two: It was concerned with practices of studied sample as reported regarding osteoporosis it included 10 items(6 items about Nutritional habits e.g. taking food rich in calcium, taking food rich in fiber vegetables, and 4 items about daily healthy habits e.g. exercise continuously.

\section{Scoring system:}

\begin{tabular}{|l|l|}
\hline Satisfactory & $>6(>65 \%)$ \\
\hline Unsatisfactory & $(\leq 6(\leq 65 \%)$ \\
\hline
\end{tabular}

Instrument three: Osteoporosis risk factors check list, it was developed by 
the researcher and included 7 items about age, irregularity of menstrual cycle, menopause, history of hysterectomy, ovaries removal, family history , and body mass index of the studied sample. 3 Items about nutritional habits (taking milk). 6 Items about reproductive history e.g. number of pregnancies, number of births, number of abortions, type of baby feeding, duration of breastfeeding, using contraceptive methods) .

\section{Scoring system:}

Scoring system for each item

\begin{tabular}{|l|l|}
\hline Yes & 1 \\
\hline No & 0 \\
\hline
\end{tabular}

\section{Content validity:}

Instruments were checked by five experts community nursing to check clarity, relevance, comprehensiveness and applicability.

\section{Ethical considerations}

Approval of faculty ethical research committee was obtained oral consent has been obtained from each working women before conducting the interview. Also women receiver a brief orientation to the purpose of the study. They were also reassured that all information gathered would be treated confidentially and used only for the purpose of the study. Women were told that they had right to withdraw from the study at any time without giving any reason.

\section{Pilot study:}

The pilot study was carried out on $10 \%$ (20) of working women. The pilot study was aimed to assess the clarity, applicability and time needed to fill each sheet, completing the sheet consumed about 30-45 minutes. Modifications were done, so the pilot study sample wasn't included in the total sample of the study.

\section{Procedure:}

1) Official letters were obtained and delivered from the Dean of Faculty of Nursing, Benha University directed to the Director of Benha University adminis-tration, then to security manager, and the security officers. The letter contained expansion of the title, objectives, instruments and the study technique.

2) The actual field work was carried out over a period of 6 months from the beginning of May 2016 to the end of October 2016. The investigator visited Benha University Administration from 9 am to $2 \mathrm{pm}$, two days per week (Sunday and Tuesday) to collect data from working women.

3) 3-Then instructions were provided about how to fill instruments two and three. it took about 20 minutes 
to fill instrument two and three.

\section{Statistical design:}

All data collected were organized, tabulated and analyzed by using the Statistical Package for Social Science (SPSS version 20), which was used frequencies and percentages for qualitative descriptive data, and $\mathrm{x}^{2}$ was used for relation tests, and mean and standard deviation was used for quantitative data, spearmean correlation test (r) was used for correlation analysis and degree of significance was identified.

Associations between items were considered as the following: ( $p$ value) Highly statistically significant $\quad \mathrm{P}<$ 0.001

Statistically Significant $<0.05$

Not significant

$$
\mathrm{P}>0.05
$$

\section{Results}

Table 1: shows that; $37.0 \%$ of studied sample ranged from 30-40 years old Mean age was $38.04 \pm 9.25$, and $68.5 \%$ they were living in rural areas. On the other hand; $54 \%$ of them had university education, $86.5 \%$ were married.

Figure 1: illustrates that $55 \%$ of studied sample had enough income, while $24.5 \%$ of them hadn $t$ enough income.

Figure 2: illustrates that $23 \%$ of studied sample had gastritis , 16\% had diabets mellitus and $12 \%$ had rheumatoid arthiritis .

Figure 3: illustrates that $12 \%$ of the studied sample were using cortisone, while $4.5 \%$ of them were using anticoagulants.

Table 2: shows that $52 \%$ and $43 \%$ respectively of the studied sample had complete knowledge regarding meaning and preventive methods of osteoporosis, While, 73\%, 91.5\% respectively of them had incomplete knowledge regarding high risk of osteoporosis.

Figure 4: illustrates that; the studied sample sources of information regarding osteoporosis were medical team for $92.2 \%, 40.6 \%$ were family and friends, $15.2 \%$ were mass media, and $4.5 \%$ were special reading.

Figure 5: illustrates that; $41 \%$ of the studied sample had poor total knowledge scores about osteoporosis and only $21 \%$ of them had good total knowledge scores.

Table 3: As regards nutritional habits of the studied sample; $12 \%, 8.5 \%$, $11.5 \%, \quad 59.5 \%, \quad 50.5 \%, \quad \& 50 \%$ respectively of them were taking food rich in calcium, fiber, and protein, reducing pickles or salts, reducing drink tea and coffee, avoiding drink soda water. Meanwhile, only $37.5 \%, 20 \%$, $37 \%, \& 12 \%$ of them were exercising 
continuously, exposing themselves to the sun light, staying away from smoking and not sitting continuously more than 6 hours at work.

Figure 6: reveals that $69.5 \%$ of the studied sample had satisfactory total practices score regarding osteoporosis and $30.5 \%$ had unsatisfactory total practices scores.

Table 4: As regards general risk factors; $49.5 \%$ of the studied sample were above 45 years old, while $45.5 \%$ of the studied sample had irregularity of menstrual cycle.30\% of the studied sample were in the period of menopause. According to nutritional habits $60 \%$ of studied sample were getting sufficient amounts of vegetables (4 times /week), while $55.5 \%$ of them were taking sufficient amount of fruits (4 times /week), and $27.5 \%$ of them were getting sufficient amounts of milk products (4 times /week).

Table 5: shows that $43.5 \%$ of the studied sample had 3-4 numbers of pregnancies. $46 \%$ had 1-2 births and $66.5 \%$ hadn't abortion. types of feeding; $64.5 \%$ were breast feeding and $57 \%$ continued breast feeding for 18 months and $65.5 \%$ of them were using contraceptive methods.

Figure 7: illustrates that $51.5 \%$ of them were using of IUD, $24.1 \%$ were using tablets, and $16.8 \%$ were using of injection.

Figure 8: illustrates that; $61.5 \%$ of the studied sample were obese, $29.5 \%$ were overweight, $7 \%$ had normal weight and $2 \%$ of them were under weight.

Table 6: reveals that there were a highly statistical significant differences between total knowledge of the studied sample having different monthly incomes $(\mathrm{P}<0.001)$, Meanwhile, there were no statistical significant differences between total knowledge score of the studied sample having different age, place of residence, level of education, marital status and nature of $\operatorname{work}(\mathrm{P}>0.05)$.

Table 7: reveals that there were highly statistical significant differences between total practices score of the studied sample having different places of residence $(\mathrm{P}<0.001)$, marital status and monthly income $(\mathrm{P}<0.05)$. On the other hand; there were no statistical significant difference total practice score of women having differences between (ages, level of education, and nature of work $(\mathrm{P}>0.05)$.

Table 8: reveals that there was a highly statistically significant correlation between total knowledge and practices scores of the studied sample regarding osteoporosis $(\mathrm{P}<0.001)$ 


\begin{tabular}{|c|c|c|}
\hline Social characteristics & No. & $\%$ \\
\hline $\begin{array}{l}\text { Age/year } \\
20- \\
30- \\
40- \\
50 \text { years or more } \\
\mathrm{X}^{2} \pm \text { SD }\end{array}$ & $\begin{array}{c}30 \\
74 \\
68 \\
28 \\
38\end{array}$ & $\begin{array}{r}15.0 \\
37.0 \\
34.0 \\
14.0 \\
5\end{array}$ \\
\hline $\begin{array}{l}\text { Place of residence } \\
\text { Rural } \\
\text { Urban }\end{array}$ & $\begin{array}{r}137 \\
63\end{array}$ & $\begin{array}{r}68.5 \\
31.5\end{array}$ \\
\hline $\begin{array}{l}\text { Level of education } \\
\text { Not read and write } \\
\text { Read and write } \\
\text { Primary education } \\
\text { Secondary education } \\
\text { University education } \\
\text { Postgraduate studies }\end{array}$ & $\begin{array}{c}5 \\
3 \\
4 \\
75 \\
108 \\
5\end{array}$ & $\begin{array}{c}2.5 \\
1.5 \\
2.0 \\
37.5 \\
54.0 \\
2.5\end{array}$ \\
\hline $\begin{array}{l}\text { Marital status } \\
\text { Single } \\
\text { Married } \\
\text { Divorced } \\
\text { Widowed }\end{array}$ & $\begin{array}{c}10 \\
167 \\
4 \\
19\end{array}$ & $\begin{array}{c}5.0 \\
83.5 \\
2.0 \\
9.5\end{array}$ \\
\hline $\begin{array}{l}\text { Nature of work } \\
\text { Written works } \\
\text { Computer works } \\
\text { Hard work (such as cleaning - lifting things }\end{array}$ & $\begin{array}{l}139 \\
38 \\
11\end{array}$ & $\begin{array}{c}69.5 \\
19.0 \\
5.5\end{array}$ \\
\hline $\begin{array}{l}\text { Daily working hours } \\
6-<9 \text { hours } \\
9-<12 \text { hours } \\
\text { 12-hours or more }\end{array}$ & $\begin{array}{c}167 \\
28 \\
5\end{array}$ & $\begin{array}{c}83.5 \\
14.0 \\
2.5\end{array}$ \\
\hline
\end{tabular}

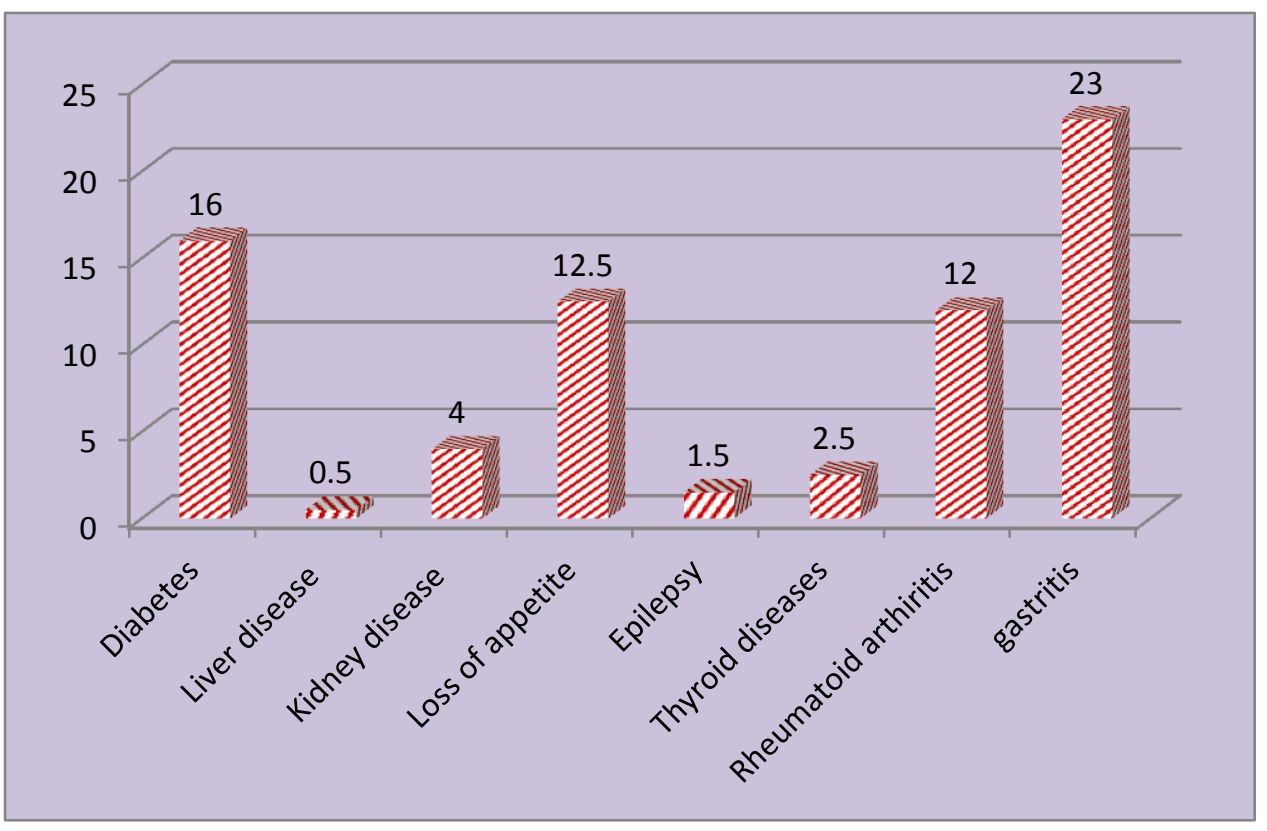

Figure (1): Percentage distribution of the studied sample regarding their health problems 


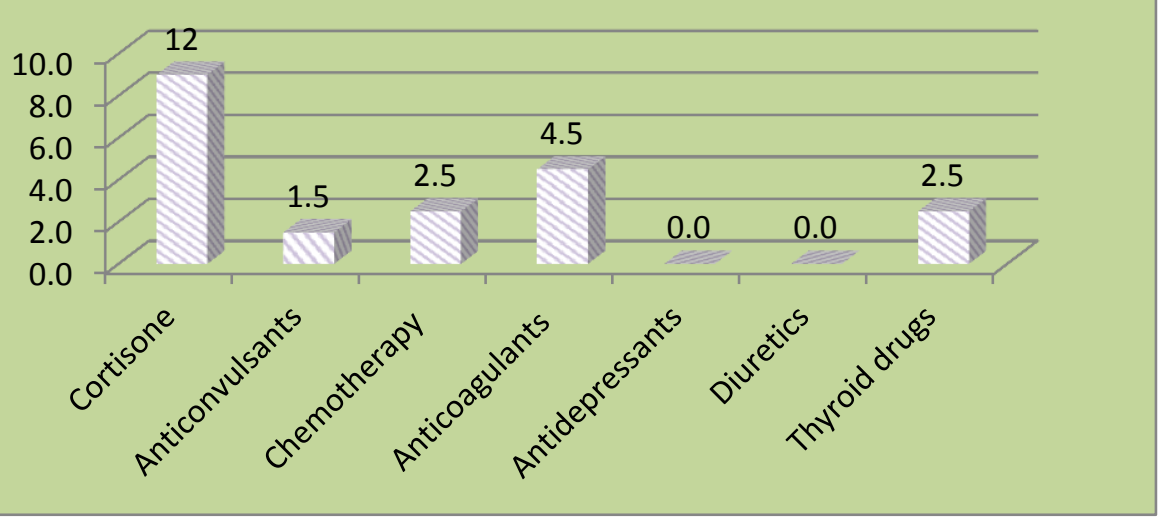

Figure (2): Percentage distribution of the studied sample regarding their taken drugs related to osteoporosis

Table (2): Frequency distribution of the studied sample regarding their knowledge about osteoporosis:

\begin{tabular}{|l|c|c|c|c|c|c|}
\hline \multirow{2}{*}{ Knowledge } & \multicolumn{2}{c|}{ Correct\&Complete } & \multicolumn{2}{c|}{ Correct\&Incomplete } & \multicolumn{2}{c|}{ Dontknow } \\
\cline { 2 - 8 } & NO. & \% & NO. & \% & NO. & \% \\
\hline Meaning & 104 & 52.0 & 76 & 38.0 & 20 & 10.0 \\
\hline Symptoms & 70 & 35.0 & 96 & 48.0 & 34 & 17.0 \\
\hline Causes & 59 & 29.5 & 72 & 36.0 & 69 & 34.5 \\
\hline High risk group & 46 & 23.0 & 146 & 73.0 & 8 & 4.0 \\
\hline The risk age (60)years & 6 & 3.0 & 183 & 91.5 & 11 & 5.5 \\
\hline Preventive methods & 86 & 43.0 & 69 & 34.5 & 45 & 22.5 \\
\hline
\end{tabular}

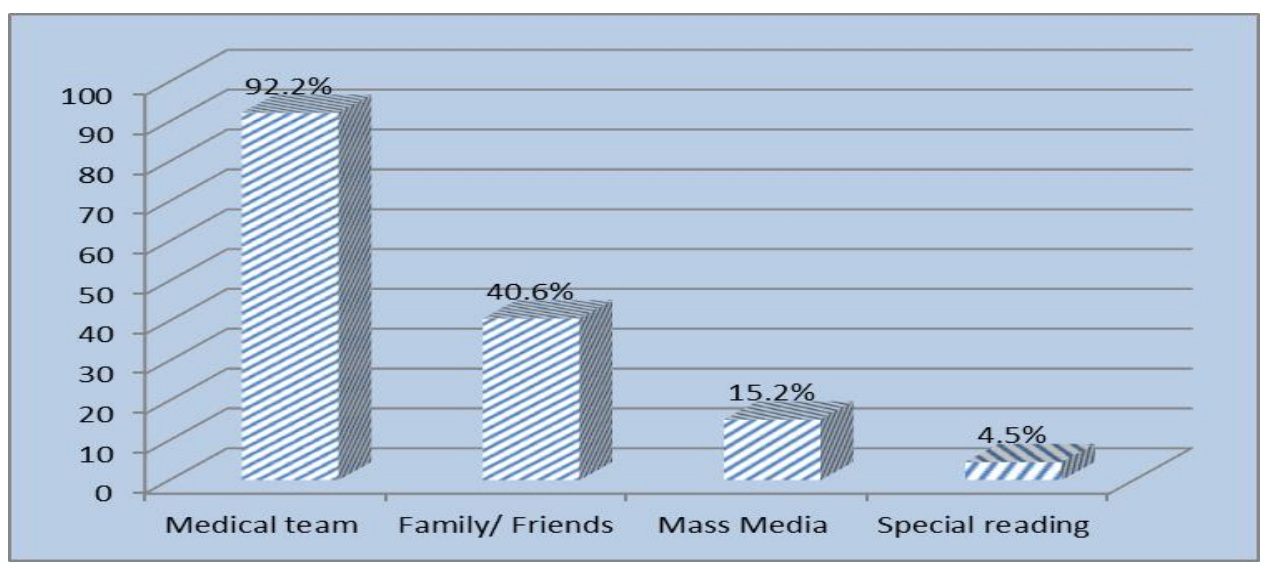

Figure (3): Percentage distribution of the studied sample regarding their source of information:

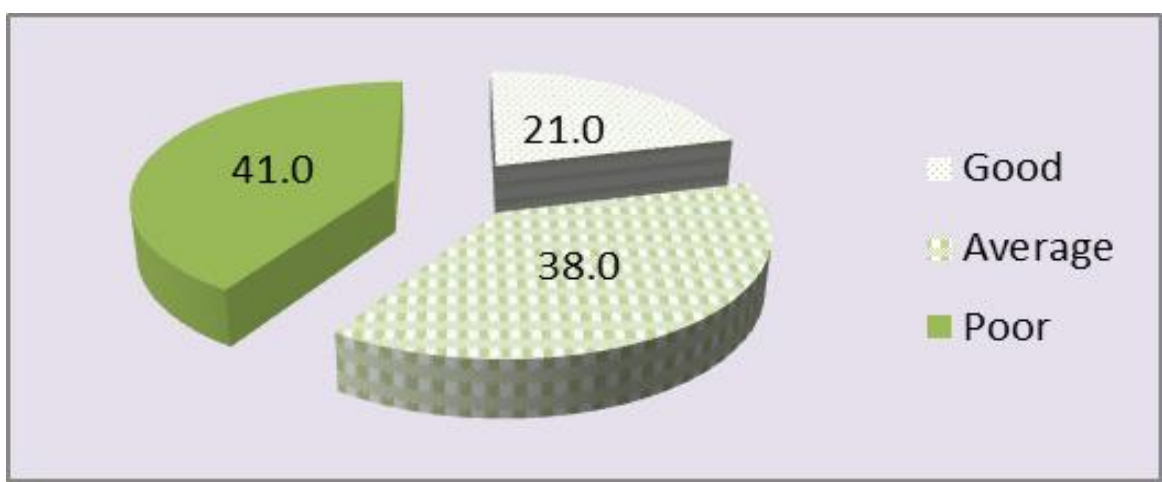


Figure (4): Percentage distribution of the studied samples' total knowledge scores regarding osteoporosis:

Table (3): Frequency distribution of the studied sample total reported practice scores regarding osteoporosis:

\begin{tabular}{|c|c|c|c|c|}
\hline \multirow[t]{2}{*}{ Practices } & \multicolumn{2}{|c|}{ Done } & \multicolumn{2}{|c|}{ Not done } \\
\hline & No. & $\%$ & No. & $\%$ \\
\hline $\begin{array}{l}\text { Nutritional habits } \\
\text { Taking food rich in calcium } \\
\text { Taking food rich in fiber vegetables } \\
\text { Taking food rich in protein } \\
\text { Reducing pickles or salts } \\
\text { Reducing drink tea and coffee } \\
\text { Avoiding drink soda water }\end{array}$ & $\begin{array}{c}24 \\
17 \\
23 \\
119 \\
101 \\
100\end{array}$ & $\begin{array}{l}12.0 \\
8.5 \\
11.5 \\
59.5 \\
50.5 \\
50.0\end{array}$ & $\begin{array}{c}176 \\
183 \\
177 \\
81 \\
99 \\
100\end{array}$ & $\begin{array}{l}88.0 \\
91.5 \\
88.5 \\
40.5 \\
49.5 \\
50.0\end{array}$ \\
\hline $\begin{array}{l}\text { Daily healthy habits } \\
\text { Exercise continuously } \\
\text { Exposure to the sun light } \\
\text { Stay away from smoking } \\
\text { Not sitting continuous more than } 6 \text { hours at work }\end{array}$ & $\begin{array}{l}75 \\
40 \\
74 \\
24\end{array}$ & $\begin{array}{l}37.5 \\
20.0 \\
37.0 \\
12.0\end{array}$ & $\begin{array}{l}125 \\
160 \\
126 \\
176\end{array}$ & $\begin{array}{l}62.5 \\
80.0 \\
63.0 \\
88.0\end{array}$ \\
\hline
\end{tabular}

(5):

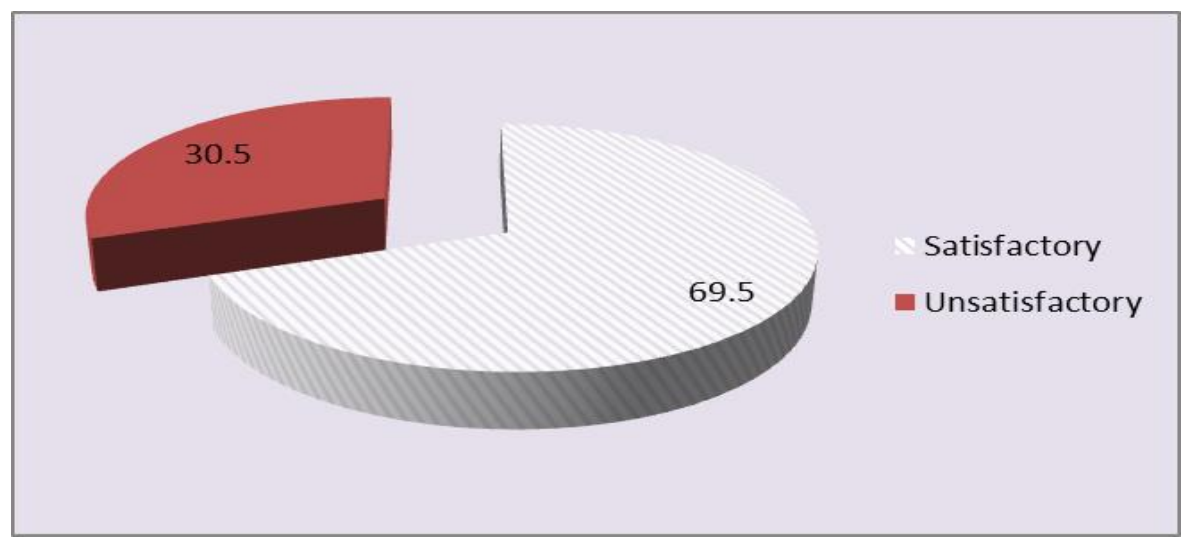

Figure

Percentage distribution of the studied sample total practices score regarding osteoporosis:

Table (4): Percentage distribution of the studied sample regarding their osteoporosis risk factors:

\begin{tabular}{|l|c|c|}
\hline General risk factors & No. & \% \\
\hline Age above 45 years(yes) & 99 & 49.5 \\
Irregularity menstrual cycle & 91 & 45.5 \\
Menopause (yes) & 60 & 30.0 \\
History of hysterectomy(yes) & 3 & 1.5 \\
Ovaries removal (yes) & 8 & 4.0 \\
Family history & 19 & 9.5 \\
\hline \hline & & \\
Nutritional habits factors & No. & $\%$ \\
\hline Taken sufficient amount of milk products 4 times/week & 55 & 27.5 \\
Taken sufficient amount of fruits 4 times /week & 111 & 55.5 \\
Taken sufficient amount of vegetables 4 times /week & 120 & 60.0 \\
\hline
\end{tabular}


Table (5): Frequency distribution of the studied sample regarding their reproductive history:

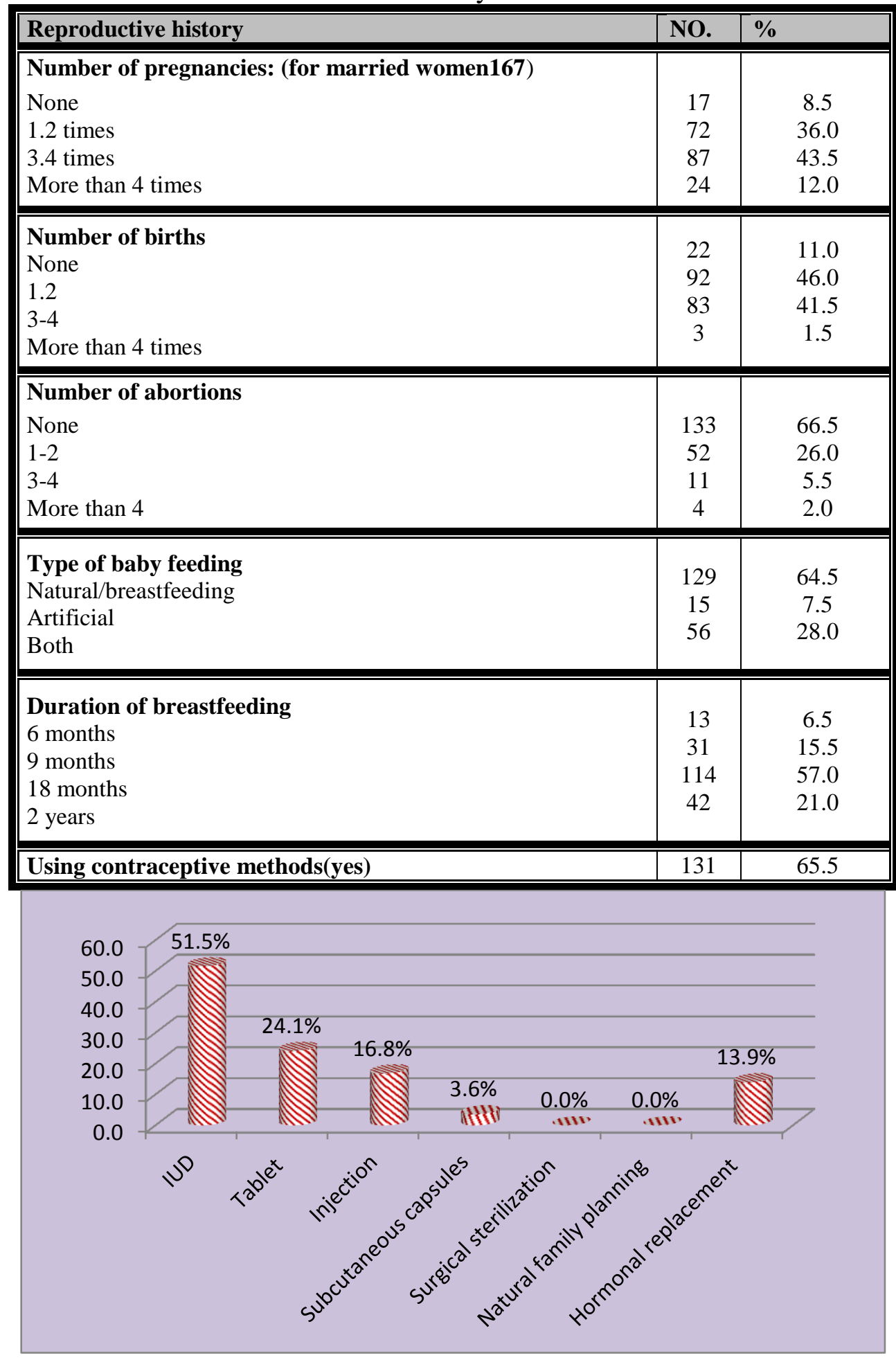

Figure (6): Percentage distribution of the studied sample regarding their contraceptive methods: 


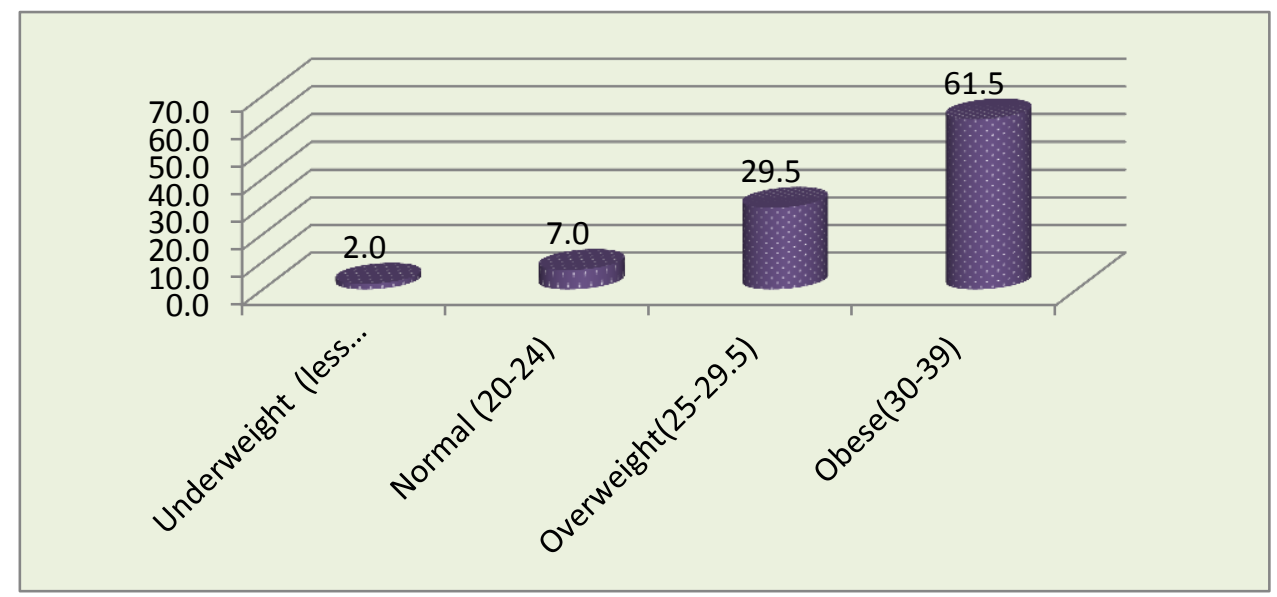

Figure (7): Percentage distribution of the studied sample regarding their body mass index

Table (6): Relation between socio-demographic characteristics of the studied sample and their total knowledge score regarding osteoporosis:

\begin{tabular}{|c|c|c|c|c|c|c|c|c|}
\hline \multirow{3}{*}{ social characteristics } & \multicolumn{8}{|c|}{ Total knowledge score } \\
\hline & \multicolumn{2}{|c|}{ Good } & \multicolumn{2}{|c|}{ Average } & \multicolumn{2}{|c|}{ Poor } & \multirow{2}{*}{$\mathrm{X}^{2}$} & \multirow{2}{*}{ P-value } \\
\hline & No & $\%$ & No & $\%$ & No & $\%$ & & \\
\hline $\begin{array}{l}\text { Age } \\
20- \\
30- \\
40- \\
50 \text { years or more }\end{array}$ & $\begin{array}{c}5 \\
14 \\
15 \\
8 \\
\end{array}$ & $\begin{array}{l}11.9 \\
33.3 \\
35.7 \\
19.0 \\
\end{array}$ & $\begin{array}{c}15 \\
30 \\
23 \\
8\end{array}$ & $\begin{array}{l}19.7 \\
39.5 \\
30.3 \\
10.5 \\
\end{array}$ & $\begin{array}{l}10 \\
30 \\
30 \\
12\end{array}$ & $\begin{array}{l}12.2 \\
36.6 \\
36.6 \\
14.6 \\
\end{array}$ & 4.07 & 0.66 \\
\hline $\begin{array}{l}\text { Place of residence } \\
\text { Rural } \\
\text { Urban }\end{array}$ & $\begin{array}{l}24 \\
18\end{array}$ & $\begin{array}{l}57.1 \\
42.9\end{array}$ & $\begin{array}{l}56 \\
20\end{array}$ & $\begin{array}{l}73.7 \\
26.3\end{array}$ & $\begin{array}{l}57 \\
25\end{array}$ & $\begin{array}{l}69.5 \\
30.5\end{array}$ & 3.49 & 0.17 \\
\hline $\begin{array}{l}\text { Level of education } \\
\text { Illiterate } \\
\text { Read and write } \\
\text { Primary education } \\
\text { Secondary education } \\
\text { University education } \\
\text { Postgraduate studies }\end{array}$ & $\begin{array}{c}0 \\
0 \\
0 \\
24 \\
17 \\
1\end{array}$ & $\begin{array}{c}0.0 \\
0.0 \\
0.0 \\
57.1 \\
40.5 \\
2.4\end{array}$ & $\begin{array}{c}2 \\
1 \\
2 \\
44 \\
25 \\
2\end{array}$ & $\begin{array}{c}2.6 \\
1.3 \\
2.6 \\
57.9 \\
32.9 \\
2.6\end{array}$ & $\begin{array}{c}3 \\
2 \\
2 \\
40 \\
33 \\
2\end{array}$ & $\begin{array}{c}3.7 \\
2.4 \\
2.4 \\
48.8 \\
40.2 \\
2.4\end{array}$ & 5.1 & 0.88 \\
\hline $\begin{array}{l}\text { Marital status } \\
\text { Single } \\
\text { Married } \\
\text { Divorced } \\
\text { Widowed }\end{array}$ & $\begin{array}{c}2 \\
37 \\
0 \\
3\end{array}$ & $\begin{array}{c}4.8 \\
88.1 \\
0.0 \\
7.1 \\
\end{array}$ & $\begin{array}{c}2 \\
63 \\
2 \\
9\end{array}$ & $\begin{array}{c}2.6 \\
82.9 \\
2.6 \\
11.8\end{array}$ & $\begin{array}{c}6 \\
67 \\
2 \\
1\end{array}$ & $\begin{array}{c}7.3 \\
81.7 \\
2.4 \\
1.2\end{array}$ & 3.71 & 0.715 \\
\hline $\begin{array}{l}\text { Monthly income } \\
\text { Enough and saving } \\
\text { Enough } \\
\text { Not enough }\end{array}$ & $\begin{array}{l}18 \\
14 \\
10\end{array}$ & $\begin{array}{l}42.9 \\
33.3 \\
23.8\end{array}$ & $\begin{array}{l}12 \\
44 \\
20\end{array}$ & $\begin{array}{l}15.8 \\
57.9 \\
26.3\end{array}$ & $\begin{array}{l}11 \\
52 \\
19\end{array}$ & $\begin{array}{l}13.4 \\
63.4 \\
23.2\end{array}$ & 17.99 & $0.001 * *$ \\
\hline $\begin{array}{l}\text { Nature of work } \\
\text { Written works } \\
\text { Computer works } \\
\text { Hard work (such as } \\
\text { cleaning - lifting things }\end{array}$ & $\begin{array}{c}29 \\
11 \\
0\end{array}$ & $\begin{array}{c}69.0 \\
26.2 \\
0.0\end{array}$ & $\begin{array}{c}52 \\
12 \\
8\end{array}$ & $\begin{array}{l}68.4 \\
15.8 \\
10.5\end{array}$ & $\begin{array}{c}58 \\
15 \\
3\end{array}$ & $\begin{array}{c}70.7 \\
18.3 \\
3.7\end{array}$ & 8.32 & 0.21 \\
\hline
\end{tabular}

Table (7): Relation between socio-demographic characteristics of the studied sample and their total practices score regarding osteoporosis. 


\begin{tabular}{|c|c|c|c|c|c|c|}
\hline \multirow{3}{*}{ Social characteristics } & \multicolumn{6}{|c|}{ Total practices score } \\
\hline & \multicolumn{2}{|c|}{ Unsatisfactory } & \multicolumn{2}{|c|}{ Satisfactory } & \multirow{2}{*}{$\mathbf{X}^{2}$} & \multirow{2}{*}{ P-value } \\
\hline & No & $\%$ & No & $\%$ & & \\
\hline $\begin{array}{l}\text { Age/year } \\
20- \\
30- \\
40- \\
50 \text { years or more }\end{array}$ & $\begin{array}{l}12 \\
21 \\
23 \\
5\end{array}$ & $\begin{array}{c}19.7 \\
34.4 \\
37.7 \\
8.2\end{array}$ & $\begin{array}{l}18 \\
53 \\
45 \\
23\end{array}$ & $\begin{array}{l}12.9 \\
38.1 \\
32.4 \\
16.5\end{array}$ & 3.90 & 0.27 \\
\hline $\begin{array}{l}\text { Place of residence } \\
\text { Rural } \\
\text { Urban }\end{array}$ & $\begin{array}{c}52 \\
9\end{array}$ & $\begin{array}{l}85.2 \\
14.8\end{array}$ & $\begin{array}{l}85 \\
54\end{array}$ & $\begin{array}{l}61.2 \\
38.8\end{array}$ & 11.4 & $0.001 * *$ \\
\hline $\begin{array}{l}\text { Level of education } \\
\text { Illiterate } \\
\text { Read and write } \\
\text { Primary education } \\
\text { Secondary education } \\
\text { University education } \\
\text { Postgraduate studies }\end{array}$ & $\begin{array}{c}0 \\
0 \\
2 \\
30 \\
27 \\
2\end{array}$ & $\begin{array}{c}0.0 \\
0.0 \\
3.3 \\
49.2 \\
44.3 \\
3.3 \\
\end{array}$ & $\begin{array}{c}5 \\
3 \\
2 \\
78 \\
48 \\
3\end{array}$ & $\begin{array}{c}3.6 \\
2.2 \\
1.4 \\
56.1 \\
34.5 \\
2.2 \\
\end{array}$ & 5.88 & 0.31 \\
\hline $\begin{array}{l}\text { Marital status } \\
\text { Single } \\
\text { Married } \\
\text { Divorced } \\
\text { Widowed }\end{array}$ & $\begin{array}{c}1 \\
47 \\
2 \\
11\end{array}$ & $\begin{array}{c}1.6 \\
77.1 \\
3.3 \\
18.0\end{array}$ & $\begin{array}{c}9 \\
120 \\
2 \\
8\end{array}$ & $\begin{array}{c}6.5 \\
86.3 \\
1.4 \\
5.8\end{array}$ & 8.4 & $0.038^{*}$ \\
\hline $\begin{array}{l}\text { Monthly income } \\
\text { Enough and saving } \\
\text { Enough } \\
\text { Not enough }\end{array}$ & $\begin{array}{c}6 \\
41 \\
14\end{array}$ & $\begin{array}{c}9.8 \\
67.2 \\
23.0\end{array}$ & $\begin{array}{l}35 \\
69 \\
35\end{array}$ & $\begin{array}{l}25.2 \\
49.6 \\
25.2\end{array}$ & 7.33 & $0.026^{*}$ \\
\hline $\begin{array}{l}\text { Nature of work } \\
\text { Written works } \\
\text { Computer works } \\
\text { Hard work (such as cleaning - lifting things }\end{array}$ & $\begin{array}{c}46 \\
11 \\
2\end{array}$ & $\begin{array}{c}75.4 \\
18.0 \\
3.3\end{array}$ & $\begin{array}{c}93 \\
27 \\
9\end{array}$ & $\begin{array}{c}66.9 \\
19.4 \\
6.5\end{array}$ & 2.35 & 0.50 \\
\hline
\end{tabular}

Table (8): Pearson correlation between total knowledge score and total practices score of the studied sample regarding osteoporosis.

\begin{tabular}{|l||c|c|}
\hline \multirow{2}{*}{ Total practices Scores } & \multicolumn{2}{|c|}{ Total knowledge Scores } \\
\cline { 2 - 3 } & $\mathrm{r}$ & P-value \\
\cline { 2 - 3 } & 0.21 & $0.001 * *$ \\
\hline
\end{tabular}

\section{DISCUSSION}

Osteoporosis is a systemic skeletal increased risk of fractures. It is a major disorder that affects bone density and health problem which affects millions of quality, leading to bone fragility and people around the world and its 
frequency increases by age. Osteoporosis is a worldwide problem because it increases with (Abdullah, 2017).

Concerning knowledge score about osteoporosis disease (Table 2). The current study showed that; slightly more than the half of the studied sample had correct and complete knowledge score regarding meaning of osteoporosis disease, and had average knowledge regarding high risk of osteoporosis, and the risk age of osteoporosis. These finding disagree with Hossien et al., (2014) who performed a study on osteoporosis knowledge among female adolescents in Egypt, and reported that; average knowledge score regarding meaning of osteoporosis was $36 \%$ and poor knowledge regarding high risk of osteoporosis were 52\%, and the risk age of osteoporosis .

As regards symptoms, causes, preventive methods of osteoporosis, the current study revealed that about one third of the study had no knowledge regarding causes, and slightly more than one fifth of them had no knowledge about symptoms, less than half of the study complete knowledge about preventive methods. These finding disagree with who performed a study on Knowledge about osteoporosis among healthy women attending a tertiary care hospital, Saudi Arabia, and reported that; the minority of the studied sample had correct and incomplete knowledge according to symptoms, causes and preventive methods related to osteoporosis .

Concerning the studied sample source of information about osteoporosis disease. this study showed that most of the studied sample received information from medical team while less than half of them received information from family or friends, one fifth from mass media and less than one tenth from special reading. These findings disagreed with Safizadeh et al., (2015) who performed a study about awareness of osteoporosis among female employee in Kerman, Iran, and stated that; the most frequent source of information about osteoporosis were radio and TV (44.6\%) followed by newspapers and magazines (41.6\%) and relatives and friends for $(41.4 \%)$. Health care workers had the least role in this regard $(9.5 \%)$.

Concerning total knowledge score of the studied sample regarding osteoporosis. this study showed that less than half of them had poor knowledge scores. This result disagreed with Osman, (2013) who performed a study on assessment of osteoporosis KAP among women in Assir region, Saudi Arabia and stated that $43 \%$ of the studied sample had good knowledge regarding osteoporosis. This 
difference could be ahirbnted to differences in the level of education between the two studied samples.

Regarding the practices of the studied sample results of the present study illustrated that slightly more than one tenth of the studied sample were taking food rich in calcium. This result disagreed with Mahboub et al., (2014) who performed a study on evaluation of the prevalence and correlated factors for decreased bone mass density among pre and postmenopausal educated working women in Saudi Arabia they stated that $60 \%$ of the studied sample took food rich in calcium.

Results of the present study showed that only $(8.5 \%)$ of the studied sample were eating food rich in vegetables and around one tenth of the studied sample were taking food rich in protein. These results disagree with Agrawal \& Verma, (2013) who performed a study on cross sectional study of osteoporosis among women in India and stated that $35 \%$ of the studied sample took food rich in vegetables and protein. Although some women had proper knowledge about healthy diet they need nutritional educational programs help them to translate their knowledge into behaviors.

Results of the study showed that more than half of the studied women reduced pickels,salts,teaor coffee in diet.
Meanwhile, more than one third of the sample were practicing regular exercise. These results agreed with Al-shammari, (2014) who performed a study on women knowledge, attitude and practices about osteoporosis prevention Saudi Arabia, and stated that $58 \%$ of the studied samples were reducing salts or pickles, and $42 \%$ were making exercise continuously. This might be due to the habit of drinking a lot of tea cups daily among all Egyptians and that caffeine was thought to provide to keep alert, productive, stay up late and concentrate well.

Furthermore, the results of the current study showed that half of the studied sample avoided drinking soda water. This result disagreed with Poslusna et al., (2008) who performed a study on risk factors of osteoporosis-knowledge and practices among adolescent females, and reported that; $29 \%$ of the studied sample were drinking soda water. These might be due to faulty habits of drinking soda water among Egyptian people.

As regards to exposure to the sunlight; the results of the current study showed that less than one quarter of the studied sample were exposed to sunlight. Also, slightly more than one third of them stayed away from smoking. These findings agreed with Jakobsen et al., (2013) who made a study on clinical risk 
factors for osteoporosis they reported that; $17.8 \%$ of the studied sample were exposed to the sunlight and $42 \%$ of them stayed away from smoking. This result might be related to staying for time in the work.

This finding was in agreement with Gebel et al., (2017) who conducted a study on patterns and predictors of sitting time over ten years in a large populationbased Canadian sample.

Concerning total practices score, the present study showed that more than two thirds of the study had satisfactory practices regarding osteoporosis. This finding disagreed with Ibrahim et al., (2014) who conducted a study on effectiveness of the implemented training program in changing menopausal women's knowledge and opinion toward osteoporosis and stated that only $15 \%$ of the studied sample had satisfactory practices regarding osteoporosis. This might be due to poor knowledge and cultural factors that may reduce women joining in sports.

Concerning osteoporosis general risk factors, the current study showed that about one half of the study group were above 45yearsand had irregular menstrual cycle. Also these findings dissimilar with Mohamed, (2009) who conducted a study on assessment and modification of nutritional risk behavior for osteoporosis among childbearing / working women, and stated that; $16 \%$ of the studied sample were 45years, 20\% had irregular menstrual cycle and 5\% were in menopause.

As regard nutritional habits less than two thirds of them were taking sufficient amounts of vegetables. while more than half were used to get sufficient amount of fruits and slightly more than one quarter were taking sufficient amount of milk products. These findings were agree with who conducted a study on increased intake of selected vegetables, herbs and fruit, and stated that; $49 \%$ of the studied sample had taken fruits,55\% of studied sample were taking vegetables, and $30 \%$ were taken milk products.

The current study revealed that; there was a highly statistically significant relationship between the total knowledge score of studied sample and their monthly income. Meanwhile there was no statistically significant relationship between total knowledge and women age, place of residence, level of education, marital status and nature of work. These findings WERE in the same line with Elsabagh et al., (2015) who conducted a study on osteoporosis knowledge and health beliefs among employees of Tanta University. Also it agreed with Riaz et al., (2008) who performed a study on Knowledge about 
osteoporosis among healthy women attending a tertiary care hospital in Saudi Arabia.

The current study revealed that there was a highly statistical significant relationship between total practices scores of the studied sample and their place of residence, marital status, and monthly income. On the other hand there were no statistical significant relationship between age, level of education, nature of work and their total practices score $(\mathrm{P}>$ 0.05). This might be low income women had a much lower intake of dairy products. this was attributed to inadequate intake of good quality of diet by low income women.

The second research question is about relationship between level of knowledge and practices. Bedsides this study revealed that there was a high statistical significant correlation between total knowledge and total practices score of the studied sample regarding osteoporosis. This finding is dissimilar with who performed a study on Effect of STP on knowledge, attitude and practice of menopausal women regarding the prevention of cardiac disease and osteoporosis in selected health center of Kannur they stated that there was no statistical significant correlation between knowledge and practice. Above all, higher level of knowledge is expected to contribute to higher level of practices.

\section{Conclusion:}

Women who have complete knowledge about meaning, symptoms, causes, high risk groups, risk age and preventive methods are only $52 \%, 35 \%, 29.5 \%$, $23 \%, 3 \%$ and $43 \%$.also, more than two thirds of women (having different social characteristics had either average or poor level of knowledge. More than half of them had either average or poor level of practices Also, there was highly statistical positive correlation between level of nurses knowledge and practices regarding care of osteoporosis.

\section{Recommendation:}

1) Health educational program should be developed and implemented for women to improve and update their knowledge and practices about osteoporosis.

2) Further studied need to be focusing on improving awareness of women about osteoporosis.

\section{References:}

Abdullah, W. (2017): Risk factors and preventive measures awareness among nursing students regarding osteoporosis, Journal of Nursing and Health Science, 6(2), Pp. 07-21. Accessed on: 20 Jule 2017.

Agrawal, T., and Verma, A. (2013): Cross Sectional Study of osteoporosis 
among women, Medical Journal, PMC 69(2), Pp:168-171. Available at:http:www.ncbi.nlm.nih.gov/pmc/ar ticles/PMC/3862785. Accessed on 13 March/ 2016.

AL-shammari, K. (2014): Women

knowledge, attitude, and practices about osteoporosis prevention "Riyadh Saudia Arabia", World Journal of Medical Sciences, 11(3), Pp:422-431. Accessed on 24 October 2016

Anbarasi, P., Ajith, A., and Stella, S. (2015): Assess the level of knowledge Prevention Osteoporosis among Working Women, Journal DOI, 4(10). Accessed on 23 Jule 2016.

Ann Gunn, C., Weber, J., $\quad$ McGill, $\quad$ A., and Kruger, M. (2015): Increased intake of selected vegetables, herps and fruit may reduce bone turn over in post-menopausal women, Multidisciplinary Digital Publishing Instituite (MDPI), 7 (4), Pp. 24992517. Accessed on 6 December 2017

Accessed on 25 December 2017.

Elsabagh, H., Aldeib, A., $\quad$ Atlam, S., and Saied, S. (2015): Osteoporosis knowledge and health beliefs among employees of Tanta University, American Journal of research communication, 3(12), Pp. 62-77. available at:
http:www.usa.Journals.com.

Accessed on: 19 March, 2016.

EL-Tawab, S., Saba, E., EL- Weshahi, H., and Ashry, M . (2015) knowledge osteoporosis among women in Alexandria Egypt: A community based survey, the Egyption Rheumatologist, Available at: http://www.sciencedirect.com/science articl/pii/S111011641000794.

Accessed on: 13 March, 2016.

Fahim, H., Bakr, I., Sayed, A., and Ismail, Gh. (2015): An interventional study for osteoporosis prevention among female employees of faculty of Medicine, Ain shams university, The Egyptian Journal of community Medicine, 33 (3), Pp: 1931. Accessed on 6 December 2017.

Gebel, K., Pont, S., Ding, D., Bauman, A., Chau, J., Berger, C., and Prior, J.(2017): Patterens and predictors of sitting time over ten years in a large population-based candian sample :findings from the candian multicenter osteoporosis study (CaMos), preventive Medicine reports, $\quad \operatorname{vol}(5), \quad$ Pp:289294.ElsevierInc. Available at:http://www.science direct.com/science/article/pii/s221133 5517300153. Accessed on 6 December 2017. 
Hackle, B., and Kriebs, J. (2016):

Primary care of Women, $2^{\text {nd }}$ ed, Jones and Barlett Publishers, U.S.A Pp.950-954.

Hannon, Ch., and Murphy, K. (2017): A survey of nurses and midwives knowledge of risks and life style factors associated with osteoporosis, Journal of Orthopedic Nursing, 11(3), Pp.30-37. Available at: www.elsevierhealth.com/journals/joo n. Accessed on 10 June 2017.

Henriques, G. (2014): Psychology Defined, Journal of clinical psychology, 60 (12), Pp. 1207-1221.available at: www.interscience willey.com.

Accessed on 10-2-2018.

Hossien, Y., Tork, H., and EL-Sabeely,
A. (2014):
Osteoporosis

knowledge among female adolescents in Egypt, American Journal of Nursing Science, 3(2), Pp. 1317.available at:

http://www.sciencepublishingroup.co $\underline{\mathrm{m} / \mathrm{j} / \mathrm{ajns}}$. Accessed on 23 October 2016.

Ibrahim, S., Nour, S., and Farahat, F. (2014): Effectiveness of the implemented training program in changing Menopausal women's knowledge and opinion toward osteoporosis, Journal of Nursing and health science (IOSR- JNHs), 3(6), Pp:62-69. Available at:
www.iosrJournal.org. Accessed on 6 December 2017.

Jakobsen, A., Laurberg, P., Vestergaard, P., and Anderson, S.

Clinical risk factors for osteoporosis are common among elderly people in Nuuk, Greenland, International Journal of circumpolar health, vol (72).available at: http://www.circumpolarhealth journal.net/index.php/ijch/articles/vie w/19596. Accessed on 26 September 2016.

Mahboub, S., Al-Mummar, M., and Elareefy, A.(2014):Evaluation of the prevalence and correlated factors decreased bone mass density among pre-and post-menopausal educated working women in Saudia Arabia, Journal of health, population and nutrition , 32 (3), Pp. 513-519. . Accessed on 31 March 2016.

Mary, J., Vijayan, A., Nair, C., Josegh, M., and Reshmi, CK.(2017): Effect of STP on knowledge, attitude, and practice of menopausal women regarding the prevention of cardiac disease and osteoporosis in selected health center of kannur district, Nursing and health care International Journal, 1(5). Accessed on 6 December 2017. 
Mohamed, H. (2009): Assessment and modification of nutritional risk behavior for osteoporosis among child bearing working women, Doctorate thesis, Faculty of nursing, Menoufiya University, Maternal and newborn nursing department.

Mohamed, Sh., and Tayel, D. (2012): Dietary behavior toward osteoporosis among women in a Slum area influenced by nutritional knowledge and stages of precaution adoption model, Journal of American Science, 8(8). Available at: http://www.jofamericanscience.org. Accessed on 23 October2016.

Osman, A. (2013): Assessment of osteoporosis KAP among Women in Assir region, Saudi Arabia, Journal of Medicine and Medical Sciences, 4(2), Pp. 50-55. Available at: http://www.interesjournals.org./jMMs . Accessed on 3 March 2016.

Puttapitakpong, P., Chaikittisilpa, S., Panyakhamlerd, K., Nimnuan, Ch., Jaisamrarn, U., and Taechakraichana, N. (2014): Inter- correlation of
Knowledge, attitude,and osteoporosis preventive behaviors in women around the age of peak bone mass, BMC women's health, Bio Med Central. Available at: http://bmcwomenhealth.Biomed central.Com/articles/10.1186/14726874-14-35. Accessed on 24 April 2016.

Riaz, M., Abid,N., Patel, J., Tariq, M., Khan, M., and Zuberi, L. (2008): Knowledge about osteoporosis among healthy women attending a tertiary care hospital, Journal of the Pakistan Medical Association, 58(4), Pp.190-194. Accessed on 10 April 2016

Safizadeh, M., Aminizadeh, E., and Safizadeh, K. (2015): Awareness of osteoporosis among female employees in Kerman, Iran Russian open Medical Journal, 4 (1), p.65. Accessed on 13 March 2016.

Stanhope, M., and Lancaster, J. (2018): Foundations for population health in community/public health Nursing, $5^{\text {th }}$ ed, Elsevier, Canda, Pp:1-33. 